\title{
Correction to: Treatment of Fat-Containing Wastewater Using Binary Flocculant Mixtures Based on Chitosan and Quaternary Salt of Poly(2-dimethylamino)ethyl Methacrylate
}

\author{
Svetlana S. Dryabina ${ }^{1}$ (D) Ksenia M. Fotina ${ }^{1} \cdot$ Yulia V. Shulevich ${ }^{1} \cdot$ Alexander V. Navrotskii $^{1} \cdot$ Ivan A. Novakov $^{1}$
}

Published online: 26 June 2019

(c) Springer Science+Business Media, LLC, part of Springer Nature 2019

\section{Correction to:}

Journal of Polymers and the Environment

(2019) 27:1595-1601

https://doi.org/10.1007/s10924-019-01454-7

The original version of this article unfortunately contained an error in the article title of Ref. [22]. The correct reference is given below:

Bigogno RG, Rodríguez RJS, Abreu MF (2018) Quaternized chitosan for ecological treatment of bauxite mining effluents. J Polym Environ 26:4169.
Publisher's Note Springer Nature remains neutral with regard to jurisdictional claims in published maps and institutional affiliations.

The original article can be found online at https://doi.org/10.1007/ s10924-019-01454-7.

Svetlana S. Dryabina

s_dryabina@vstu.ru

1 Volgograd State Technical University, Lenin Avenue 28, Volgograd, Russia 400005 